\title{
Discurso antigênero e agendas feministas e LGBT nos planos estaduais de educação: tensões e disputas
}

\author{
Cláudia Vianna ${ }^{1}$ \\ ORCID: 0000-0002-9366-4417 \\ Alexandre Bortolini ${ }^{1}$ \\ ORCID: 0000-0001-8769-6837
}

\section{Resumo}

Este artigo apresenta resultados de pesquisa sobre o uso do gênero nos 25 planos estaduais e distrital de educação promulgados entre 2014 e 2016. Demonstramos que as disputas em torno das questões de gênero nos planos evidenciam que não existe apenas uma forma de excluir ou incluir o tema, a saber: o veto; a omissão do termo e de outros a ele relacionados; a explicitação do gênero como um direito das mulheres e da população LGBT para a garantia de acesso e de permanência à educação de qualidade e o uso parcial com referências aos direitos humanos, à garantia de alguns direitos das mulheres e à cultura da paz. Mais da metade dos planos inseriu questões relativas à agenda das mulheres, sob uma perspectiva de gênero. Quase um terço dos planos expressam clareza de que a garantia de acesso e permanência com qualidade passa pelo enfrentamento das desigualdades de gênero. 0 caráter fixo e binário da oposição entre significados masculinos e femininos foi problematizado ao se incluir o combate ao sexismo, ao machismo e à LGBTfobia. Entretanto, vários planos manifestam o avanço de pautas conservadoras com a exclusão do gênero, corte ou limitação da agenda LGBT e inserção de itens que submetem a abordagem destes temas na escola à concordância das famílias. Conclui-se que o avanço conservador antigênero, ao menos no momento examinado, contrapõe-se à manutenção de várias conquistas. Permanecem, portanto, as contradições nas disputas de poder pela contribuição do gênero na função social da educação.

\section{Palavras-chave}

Política educacional - Gênero - Plano estadual de educação - LGBT - Agenda antigênero.

1- Universidade de São Paulo, São Paulo, SP, Brasil. Contatos: cpvianna@usp.br; bortolini.alexandre@gmail.com

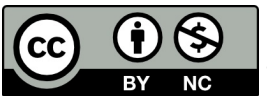




\section{Anti-gender discourse and LGBT and feminist agendas in state-level education plans: tensions and disputes}

\section{Abstract}

This article presents the results of a research on the use of gender in education plans of 25 Brazilian states and the Federal District, enacted between 2014 and 2016. We demonstrate that the disputes around the gender issues in the plans bespeak that there is not just one way of excluding or excluding the topic, namely: the veto; leaving out the word and other related terms; the specification of gender as women's right and the right of the LGBT community in order to ensure access to and permanence in quality education, and the partial use associated with human rights, the guarantee of some women's rights, and the culture of peace. Over half the plans included issues related to the women's agenda in a gender perspective. Almost one third of the plans clearly express that ensuring access and permanence with quality involves confronting gender inequalities. The fixed and binary nature of the opposition between male and female meanings was problematized when fighting sexism, machismo, and LGBTphobia was embraced. However, several plans indicated the move of conservative agendas by excluding gender, by cutting or limiting the LGBT agenda, and by including items that demand that dealing with such topics be subject to family approval. Conclusion is that the conservative anti-gender advance, at least in the period under screen, is opposed to maintaining a number of political achievements. Therefore, contradictions remain in the disputes of power through the contribution of gender in the social function of education.

\section{Keywords}

Educational policy - Gender - Education state-level plan - LGBT - Anti-gender agenda.

Neste artigo são expostos e analisados resultados de pesquisa em fase de finalização ${ }^{2}$ acerca de como perspectivas críticas sobre as relações de gênero e a produção das sexualidades foram explicitadas, omitidas, inseridas parcialmente ou mesmo vetadas nos planos estaduais e distrital de educação (PEE) promulgados entre 2014 e 2016, a partir de agora denominados planos de educação.

A investigação partiu do processo de democratização da educação com foco em suas políticas públicas sob a ótica das relações sociais de gênero. A proposta foi dialogar com a já vasta produção acadêmica sobre gênero e sexualidade na educação, inicialmente difundida no Brasil por Guacira Lopes Louro $(1999,2006)$ e largamente ampliada ao longo das últimas décadas, conforme balanços mais recentes (VIANNA; UNBEHAUM, 2016;

2- A pesquisa, coordenada por Cláudia Vianna, contou com apoio do CNPq/PQ (2015-2019) e também com a imprescindível contribuição de Alexandre Bortolini. 
VIANNA, 2018). A investigação, cujos resultados são apresentados neste artigo, opera com o gênero como um conceito capaz de apreender a construção social e histórica das relações sociais que lhe dizem respeito, articulada aos múltiplos processos de dominação cultural, econômica, política e simbólica (SCOTT, 1995, 2011) e, portanto, como categoria fértil para a análise das políticas de educação, entendidas como um processo de elaboração - tenso e negociado - entre grupos que reivindicam interesses concretos do Estado. Se considerarmos que a análise do processo de elaboração das políticas educacionais deve partir da identificação dos respectivos grupos que reivindicam do Estado interesses de cunho material e simbólico (CUNHA, 2002), é possível examinar essas políticas não apenas enquanto reivindicações, mas como respostas materializadas na forma de documentos, planos, programas e ações (VIEIRA, 2007) resultantes de disputas acirradas.

A investigação buscou compreender o modo como o recente debate em torno da aprovação dos planos de educação foi atravessado por essas disputas, opondo setores ligados ao ativismo feminista e $\mathrm{LGBT}^{3}$ a grupos organizados em torno do combate à introdução de perspectivas de gênero nas políticas públicas. A finalidade foi captar a linguagem e o conteúdo dos planos de educação (PEE) enquanto documentos indicadores de intencionalidades, interesses, disputas de poder em torno de distintas concepções de educação, bem como interrogar como perspectivas críticas sobre as relações de gênero e a produção das sexualidades foram inseridas ou, em casos extremos, excluídas destas normativas educacionais.

Nesta análise, buscamos identificar a inserção das questões de gênero e sexualidade nos planos de educação, promulgados entre 2014 e 2016. A explicitação, a inserção parcial, a omissão ou o veto dessas dimensões nos planos nos dão indícios do quanto e de que forma esses temas foram negociados na elaboração das políticas educacionais no âmbito dos estados e do Distrito Federal. Levantamos todos os planos disponíveis relativos ao próximo decênio. Os estados de Minas Gerais e Rio de Janeiro, até a finalização deste artigo, não haviam aprovado plano de Educação para o período. Examinamos, portanto, vinte e quatro planos estaduais e um plano distrital de educação.

As informações aqui analisadas foram levantadas nas plataformas digitais públicas dos legislativos estaduais e distrital. 0 acesso à informação que estas plataformas permitem varia entre as unidades da federação. Em algumas estava disponível apenas o texto definitivo da lei, em outras pudemos também acessar o projeto de lei original e em algumas foi possível visualizar todo o processo legislativo, com emendas, atas, relatórios de comissões e outros documentos disponíveis.

Neste artigo, priorizamos o texto contido na publicação da versão definitiva da lei, mas sem deixar de lado a compreensão de que não se trata de uma versão estática, mas, sim, carregada das contradições e disputas de poder em torno do papel das relações de gênero e da produção das sexualidades na educação. Demonstramos que os planos de educação recentemente votados mostram em seus textos tensões e disputas entre: a explicitação

3- A sigla LGBT (Lésbicas, Gays, Bissexuais, Travestis, Transexuais e Trangêneros), aqui adotada, segue deliberação da I Conferência Nacional LGBT, realizada em 2008. Sabemos, no entanto, que ela não é suficiente para abarcar as múltiplas formas de expressão e identificação sexuais e de gênero. É utilizada, portanto, em um sentido abrangente, abarcando diferentes identificações de gênero (pessoas travestis, transexuais, transgêneras, homens trans, não bináries, agender, queer) e sexualidade (pessoas homossexuais, bissexuais, pansexuais, assexuais) existentes e ciente de que esse processo está em permanente construção. 
do gênero como importante ferramenta para o enfrentamento das desigualdades de gênero nas mais variadas instâncias, modalidades e níveis da educação brasileira; o uso parcial do gênero com referências às mulheres, aos direitos humanos e à cultura da paz; a omissão do termo gênero e de outros a ele relacionados ou até mesmo o veto.

\section{Gênero e produção das sexualidades nas políticas públicas de educação}

0 exame do contexto no qual se dá a produção das políticas públicas de educação a partir da perspectiva das relações sociais de gênero evidencia um tenso processo de negociação que determina a concretização, mas também a supressão de reformas, planos, projetos, programas e ações implementados, separada ou articuladamente, pelo Estado e pelos movimentos sociais e ações coletivas que pressionam por novas políticas públicas, pela ocupação de espaços na administração pública e pelo reconhecimento de novas formas de desigualdade. Tanto o Estado quanto os movimentos sociais, nas suas respectivas pluralidades, articulam-se e/ou disputam acirradamente interesses sociais presentes nesse processo. Nessa arena de relações necessariamente conflituosas e, por vezes, contraditórias, a formulação dessas políticas remete à discussão de complexidades.

A partir de meados de 1990 e início de 2000, houve uma abertura gradual da educação para a discussão das relações de gênero no âmbito das políticas públicas. Estudos realizados nas últimas décadas revelam a introdução de perspectivas de gênero e de abordagens sócio históricas das sexualidades nas políticas públicas de educação. A retomada efetiva dessa questão na área educacional se deu a partir de 1995, com a pressão de movimentos de mulheres e com as sucessivas respostas do governo de Fernando Henrique Cardoso aos compromissos internacionais relativos a uma agenda de gênero e sexualidade, juntamente com as Metas do Milênio e da Conferência de Dakar na esfera da educação (ANDRADE, 2004; VIANNA; UNBEHAUM, 2004).

No governo de Luiz Inácio Lula da Silva, esse movimento segue ascendente, e passa a incluir também o reconhecimento da diversidade de orientações sexuais e identidades de gênero de forma mais explícita e substantiva, ainda que com muitas tensões.

Nessa arena de relações necessariamente conflituosas e, por vezes, contraditórias, a formulação dessas políticas envolve vertentes teóricas e ações coletivas circunscritas ao Movimento de Mulheres e ao Movimento de Lésbicas, Gays, Bissexuais, Travestis, Transexuais e Transgêneros (LGBT). Ambos assumiram papel protagonista na proposição de vários projetos e programas federais e estaduais ligados à inclusão da diversidade sexual no contexto escolar. Também exerceram grande influência setores representativos de forças internacionais, com participação decisiva na vida nacional e na confecção de linhas de ação para as políticas públicas de educação. A organização do primeiro Plano Nacional de Políticas para as Mulheres (PNPM), em 2004, e de sua segunda versão em 2008, ambos antecedidos pelas Conferências de Políticas para as Mulheres (2004 e 2007), e do Programa Brasil Sem Homofobia (BSH), em 2004, são alguns exemplos.

Vale enfatizar que esse processo se constituiu em uma conquista das mulheres, das pessoas LGBT e de outros sujeitos coletivos politicamente organizados no desenvolvimento de agendas, por vezes conjuntas, por vezes diferenciadas, mas recorrentemente convergentes. A 
implementação desta agenda na educação brasileira; a implantação de políticas de formação de profissionais da educação na perspectiva de gênero, sexualidades e direitos reprodutivos; a menção ao tema em materiais didáticos e exames nacionais; a ampliação da educação sexual nas escolas; a normatização do reconhecimento da identidade de gênero de pessoas trans em várias instituições e sistemas de ensino e a inserção dessas dimensões em diferentes diretrizes educacionais são exemplos dessas conquistas, registradas em várias pesquisas (ANDRADE, 2004; CARREIRA, 2015; FERNANDES, 2011; LOURO, 2006; DESLANDES, 2016, entre outros).

É importante destacar que este foi o tom das políticas de gênero e diversidade sexual privilegiadas no exercício dos dois mandatos do governo de Luiz Inácio Lula da Silva - um entre 2003/2006 e outro entre 2007/2010 - marcando os planos e programas no campo educacional. Mas não se pode inferir que esse trajeto tenha sido linear rumo aos grandes avanços que pudessem garantir a introdução e a institucionalização de todas as demandas negociadas. Muito pelo contrário. Foram tempos de organização de demandas, mas também de duros embates e resistências.

Em pesquisa sobre a construção da agenda das diversidades nas políticas de educação dos governos de Luiz Inácio Lula da Silva e Dilma Rousseff, Denise Carreira (2015) destaca as disputas em torno da construção da agenda de gênero. Uma delas dizia respeito ao fato de que as agendas das diversidades roubaram paulatinamente a cena, mesmo antes da eleição de Luiz Inácio Lula da Silva em 2003. Ao longo do primeiro mandato assistimos à pressão dos movimentos sociais no processo de construção negociada da noção de diversidade como possível agregadora das agendas para a política educacional "em tensão permanente com a noção de ações afirmativas, fortalecida a partir de Durban, e com a noção de inclusão social, hegemônica no governo federal" (CARREIRA, 2015, p. 173). Outra característica dessa disputa foi a precariedade e a fragmentação, até mesmo parcialidade, do modo como essas agendas foram introduzidas. E, finalmente, vale lembrar das resistências sistemáticas de vários setores da sociedade como um todo, do Congresso e do governo e também do próprio Ministério da Educação (MEC).

A visibilidade dada à temática nas políticas educacionais colocou em pauta questões antes ignoradas, principalmente por serem consideradas tabus no ambiente escolar. Nesse aspecto, podemos dizer que deu voz a temas até então silenciados, aproximandose do que Ball define como "políticas de mudança" para referir-se à apropriação dessas políticas federais pela micropolítica das escolas, que levam "à superfície os conflitos e diferenças subterrâneas que de outro modo ficariam silenciados na rotina cotidiana da vida escolar" (BALL, 1989, p. 45).

Esse processo de avanço, ainda que precário e tenso, encontra um ponto de inflexão no veto perpetrado pelo governo de Dilma Roussef ao conjunto de materiais do projeto Escola Sem Homofobia. Gerido pelo MEC e executado desde 2009 por um conjunto de organizações não governamentais, o projeto previa a realização de seminários com profissionais da educação, gestores(as) e representantes da sociedade civil, o desenvolvimento de uma pesquisa sobre o tema em onze capitais e cinco regiões do país e a criação de um conjunto de materiais educativos. 0 conjunto, conhecido como "kit", era composto de um caderno pedagógico com atividades para uso de professores(as) em sala de aula; seis boletins para discussão com 
estudantes e três audiovisuais, cada um deles com um guia, um cartaz e cartas de apresentação para gestores(as) e educadores(as).

Todavia, após pressão da bancada religiosa conservadora no Congresso Nacional, a presidenta Dilma Rousseff vetou o material em maio de 2011, alegando sua inadequação. De acordo com o MEC, o veto referia-se aos três vídeos que exibiam histórias de afirmação das identidades de gênero e orientações sexuais por estudantes que questionavam os padrões heteronormativos das escolas. 0 restante do conteúdo ainda poderia ser distribuído nas instituições públicas de ensino. Mas isso não ocorreu, revelando a tensão entre a defesa versus o combate do gênero e da diversidade sexual nas políticas de educação. 0 veto ao "kit" não foi um episódio isolado, nesse trajeto foi possível registrar o recuo do governo federal com a perda de muitas das agendas conquistadas (FERNANDES, 2011; CARREIRA, 2015; DESLANDES, 2016; VIANNA, 2018).

Muitas dessas conquistas, que nunca foram estruturais, já possuíam frágil sustentação e continuidade incerta. Mas esse foi talvez o primeiro episódio que mais explicitamente revelou a tensão entre a defesa versus o combate da diversidade sexual e de gênero nas políticas de educação, parte de um movimento mais amplo de enfrentamento à inclusão do gênero nas políticas públicas não só no Brasil, como em diferentes partes do mundo.

Em um esforço de reconstrução dessa história, Sonia Corrêa (2018) reconhece que não há precisão quanto ao início destes afrontamentos, mas a versão mais difundida localiza a Conferência Internacional sobre População e Desenvolvimento (CIPD), mais conhecida como Conferência do Cairo, realizada em setembro de 1994, e a IV Conferência Mundial sobre a Mulher: Igualdade, Desenvolvimento e Paz, organizada pelas Nações Unidas em Pequim no ano de 1995, como marcos de acirrados debates.

A Conferência do Cairo foi responsável pela explicitação dos direitos reprodutivos, bem como o direito à informação e suporte necessários para essa decisão. Já a IV Conferência Mundial sobre a Mulher foi palco de um intenso debate sobre os direitos sexuais, ou seja, o direito de viver a própria sexualidade e a reprodução livre de discriminação, coerção ou violência.

Durante a Conferência do Cairo, o Vaticano tentou impedir, em vão, a utilização dos termos gênero ou famílias, no plural. Fazendo frente aos movimentos em defesa dos direitos reprodutivos e sexuais das mulheres, a Santa Sé organizou-se de forma mais incisiva durante a IV Conferência Mundial sobre a Mulher opondo-se à agenda feminista ao defender um discurso generalista e assumir-se como porta voz dos direitos humanos, e das mulheres, ainda que representados exclusivamente por homens. 0 recrudescimento dessa verdadeira cruzada contra o gênero (JUNQUEIRA, 2017) ganhou fôlego no início do século XXI. Setores mais conservadores da Santa Sé tomaram como ponto de partida a crítica das teorias feministas, criando um contradiscurso teológico que acusa organismos internacionais, entre eles a Organização das Nações Unidas (ONU), de difundir o que passou a ser denominado como "ideologia de gênero".

Exemplos do investimento da Igreja Católica contra o gênero são o Léxicon de termos ambíguos e discutíveis sobre a vida familiar e ética (JOÃO PAULO II, 2003) ${ }^{4}$

4- 0 Léxicon é um documento elaborado pela Igreja Católica contra a agenda feminista de defesa das necessidades de saúde reprodutiva interrelacionadas com outros direitos sociais e individuais. 
e a Carta aos Bispos da Igreja sobre colaboração do homem e da mulher na Igreja e no mundo (CONGREGAÇÃO..., 2004). 0 primeiro documento apresenta a expressão "ideologia de gênero" definida como parte de agenda feminista radical voltada para o esfacelamento da família, a partir do questionamento das diferenças sexuais. Já a Carta aos Bispos da Igreja interroga as premissas dos estudos de gênero, mais especificamente as críticas à heteronormatividade.

Como reação ao avanço da perspectiva de gênero a contraofensiva católica articulou-se com representantes religiosos conservadores de conferências episcopais, dos movimentos pró-vida e pró-família e com setores não necessariamente religiosos da extrema direita. Essa ofensiva foi progressivamente proferida no âmbito transnacional nas últimas décadas e inúmeras reflexões chamam a atenção para a dimensão transnacional desse fenômeno caracterizado por muitos como uma cruzada, campanha ou ofensiva antigênero (REIS; EGGERT, 2017; LUNA, 2017; SILVA; CÉSAR, 2017; CASTELLS, 2017; CORNEJO-VALLE; PICHARDO, 2017; JUNQUEIRA, 2017; CORRÊA, 2018; PRAD0; CORREAA, 2018). Esta cruzada teve como resultado a exclusão destes termos não só do PNE, como também de parte dos planos estaduais de educação. Mas, novamente, vale ressaltar o caráter não linear desse processo.

No campo específico da educação, a empreitada reacionária aumentou tanto na defesa de valores morais tradicionais e posições religiosas no campo da bioética (JUNQUEIRA, 2017) quanto contrárias às reformas jurídicas, políticas sociais em geral e, especificamente, nas áreas da saúde e da educação, como educação sexual, valorização das diferentes orientações sexuais, da pluralidade na composição familiar e reconhecimento da identidade de gênero como autodeterminada.

Esta cruzada teve reflexos na votação do plano nacional de educação. Em um cenário político tensionado, grupos conservadores - defensores de soluções violentas para questões sociais, ruralistas, religiosos católicos e evangélicos -, com o apoio de outros grupos religiosos (kardecistas e judeus) ou não religiosos reunindo distintos profissionais, mas também o Movimento Brasil Livre $(\mathrm{MBL})^{5}$ e o Movimento Escola Sem Partido (ESP) ${ }^{6}$ atuaram de forma coordenada durante a tramitação do plano nacional de educação no Congresso culminando na retirada das menções às questões de gênero. A versão final do plano nacional de educação (2014-2024), sancionada como lei, aprovou como meta o combate às desigualdades educacionais, referindo-se de forma genérica à erradicação de todas as formas de discriminação.

Embora o texto final siga dando respaldo legal a ações de enfrentamento à LGBTfobia, ao reconhecimento e valorização da diversidade sexual e de gênero e à promoção dos direitos sexuais e reprodutivos, a supressão das referências explícitas ao

\footnotetext{
5- 0 Movimento Brasil Livre (MBL) emerge nas manifestações ocorridas no Brasil em 2014 contra a ex-presidenta Dilma Rousseff (do Partido dos Trabalhadores), com pautas ligadas ao combate à corrupção e ao liberalismo econômico. Ocupa um lugar importante na disseminação de pautas conservadoras como: a redução da maioridade penal, a proibição do direito ao aborto, a oposiç̧ão ao casamento entre pessoas do mesmo sexo e a instrumentalização das escolas no que eles chamam de "ideologia de gênero". Por exemplo, é do MBL o chamamento público para as manifestações contra a exposição Queermuseum em Porto Alegre (2017) ou a vinda da filósofa Judith Butler (2017) para um evento em São Paulo. 6- 0 ESP foi criado em 2004 pelo advogado Miguel Nagib, procurador do Estado de São Paulo, e se apresenta como uma "iniciativa conjunta de estudantes e pais preocupados com o grau de contaminação político ideológica das escolas brasileiras" (http://escolasempartido.org/quemsomos). As pesquisas mostram que se trata de movimento de ataque e censura à crítica histórico-social nas escolas, uma articulação reacionária que associaria políticas feministas e LGBT à "esquerda", tendo como objetivo expurgar simultaneamente o "marxismo cultural" e a "ideologia de gênero" das políticas educacionais e práticas escolares (FRIGOTTO, 2017).
} 
gênero serviu para sustentar discursos de que o PNE teria vetado tudo o que pudesse ser associado à "ideologia de gênero" nas políticas educacionais.

Essa narrativa marcou profundamente o processo elaboração dos planos estaduais e distrital de educação, foco específico deste artigo.

\section{Os planos estaduais e distrital de educação}

0 processo de construção dos planos de educação nos estados e no Distrito Federal é variado, com diferentes graus e modos de participação social. 0 plano se materializa em uma lei, cujo projeto inicial é necessariamente elaborado pelo executivo, que o encaminha à Assembleia Legislativa. Avaliado - e eventualmente modificado - nas comissões e no plenário do legislativo, por meio de emendas ou substitutivos, o projeto retorna ao executivo, que pode vetá-lo em parte, vetos que serão mantidos ou derrubados pela assembleia, chegando-se à publicação defınitiva da lei.

A maior parte das leis aqui analisadas segue basicamente a mesma estrutura do plano nacional de educação: há um texto da lei, propriamente dito, organizado em artigos, parágrafos e incisos, que define diretrizes, objetivos, entre outras questões mais gerais, seguido de um anexo onde se pode encontrar as metas e suas respectivas estratégias. Dos planos examinados, catorze apresentam um anexo único com as metas e estratégias e onze incluem, além delas, um diagnóstico ou análise situacional da educação em cada estado. Dado que mais da metade dos estados não apresentam esse último item, excluímos o diagnóstico ou análise situacional de nosso estudo.

Como os planos de educação estão estruturados de forma parecida, algumas contradições nos textos saltam aos olhos, o que facilita a percepção das variações locais das disputas em torno destes temas. A análise dos planos traça um mapa que revela o resultado da negociação, mas também as várias disputas, cujos sentidos e características se materializam no texto da lei.

É importante chamar a atenção para o fato de que, diante do que encontramos, não parece possível, nem mesmo útil, organizar dicotomicamente os planos entre os que falam ou não falam sobre gênero. Não se trata, portanto, de dividi-los entre os que são contra ou a favor, entre os que vetam ou os que promovem a incorporação de uma perspectiva de gênero na política educacional, mas perceber as diferentes formas com que estes planos lidam com essas questões e o que isso nos indica sobre os processos de disputa política em que eles foram forjados. 0 que descobrimos?

0 detalhamento apresentado a seguir mostra que as disputas em torno das questões de gênero nos 25 planos de educação evidenciam que não existe apenas uma forma de excluir ou incluir o tema. Tratar o gênero como objeto de disputa e enfrentamento de políticas antigênero na educação com foco em seu tratamento nos planos de educação significa assumir o desafio de romper com o entendimento sobre a "ideologia de gênero" como a estratégia de ocultação ou cortina de fumaça frente a questões mais sérias em nossa sociedade. A "ideologia de gênero" nesse contexto não é um conceito e nem uma categoria de análise, trata-se de uma categoria acusatória fortemente utilizada em um contexto no qual a "lógica antigênero deixou de ser uma estratégia de mobilização política dispersa no tecido sócio-institucional para se converter em política pública explícita" (PRAD0; CORRÊA, 2018, p. 447) e resignificada na disputa que se desdobra nos planos de educação e no entendimento da própria função social da educação. 
Os 25 planos de educação examinados - 24 estados e o Distrito Federal - podem ser divididos em quatro grupos. Alguns estados abordam aspectos que integram dois grupos, mas optamos por incluí-los no grupo cuja tendência está mais explicitamente defendida em cada um dos planos de educação examinados.

0 primeiro grupo (vermelho) diz respeito ao veto e é composto de apenas um estado (CE).

0 segundo grupo (azul) com três estados, é caracterizado pela omissão do termo gênero e de qualquer termo a ele relacionado (G0, PE, SP).

0 terceiro agrupamento (amarelo), com catorze estados (AP, AC, AL, ES, DF, PB, PI, PR, RN, RO, RS, SC, SE, T0), é marcado por incorporação parcial, com referências aos direitos humanos, à garantia de alguns direitos das mulheres e à cultura da paz, mas de forma restrita, por vezes reiterando perspectivas binárias, por vezes evocando a precedência da família sobre a escola. Em nenhum destes planos aparecem referências às demandas LGBT.

0 quarto grupo (verde) com sete estados, opera com a explicitação de questões de gênero e sexualidade, tanto no que diz respeito à superação de desigualdades e promoção dos direitos das mulheres, quanto no reconhecimento, proteção e promoção de direitos das pessoas LGBT (AM, BA, MA, MT, MTS, PA, RR).

As quatro formas de tratamento do gênero e da produção das sexualidades podem ser melhor visualizadas no mapa apresentado e serão detalhadas na Figura 1.

Figura 1 - Formas de tratamento do gênero e da produção das sexualidades por estado

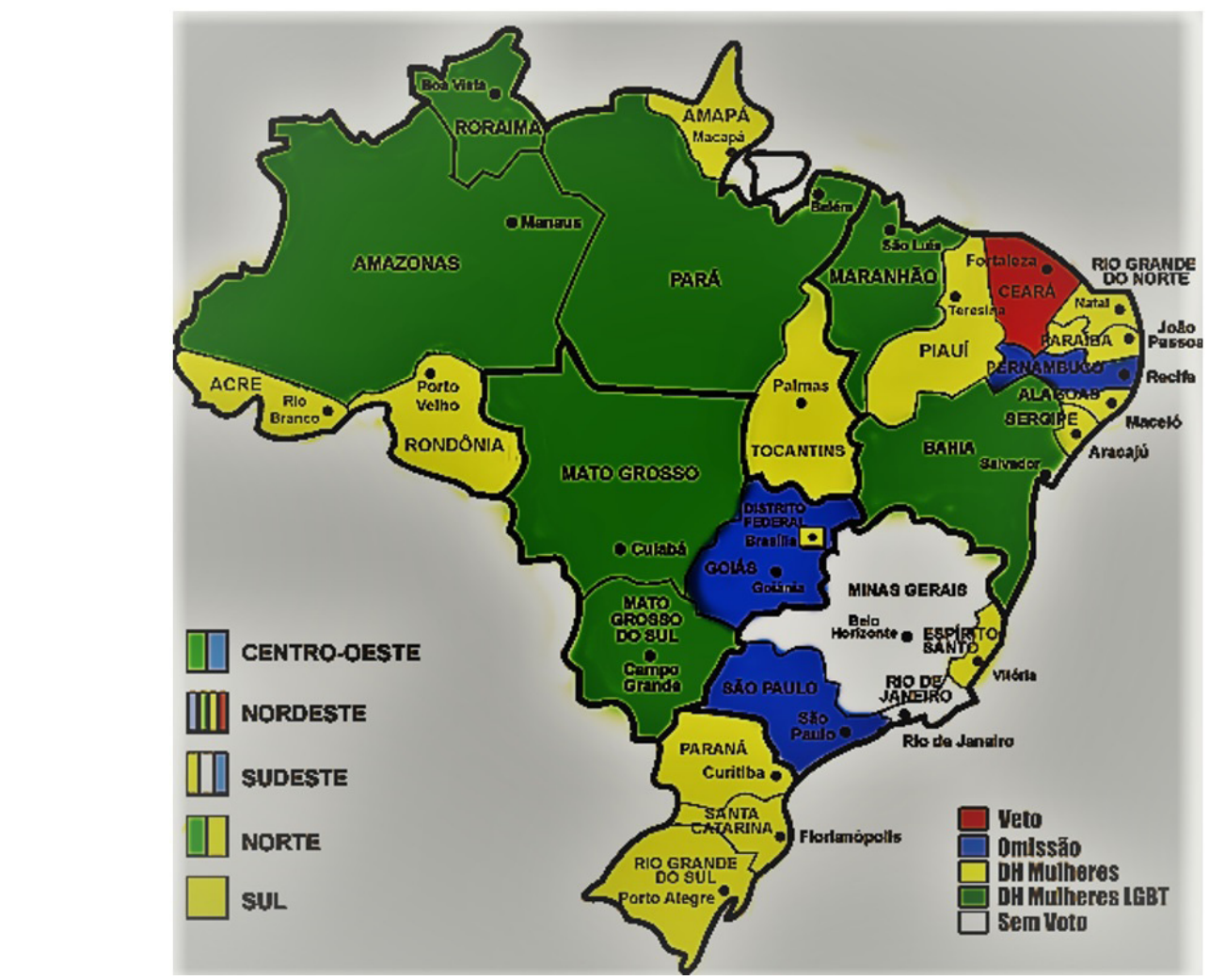

Fonte: dados da pesquisa. 


\section{O veto ao gênero (CE)}

De todos os planos de educação analisados, o PEE do Ceará é o único que inclui em suas diretrizes um inciso que explicitamente "impede, sob quaisquer pretextos, a utilização de ideologia de gênero na educação estadual” (CEARÁ, 2016, Art. 3º Inciso XV, grifos nossos).

Esse veto, no entanto, convive com menções que, a princípio, parecem contraditórias. Na Meta 21, Estratégia 21.10, o plano indica “ajustes nos currículos das escolas indígenas, quilombola e do campo" para inserir conteúdos que ajudem a

[...] desenvolver cultura de superação do preconceito e discriminação aos segmentos populacionais, inclusive por racismo, por sua orientação sexual, machismo, intolerância religiosa e geração, etnia, agroecologia, gestão territorial, medicina tradicional, pintura corporal e rituais indígenas, etc.) que atendam a realidade e as especificidades dessas comunidades. (CEARÁ, 2016, grifos nossos).

A Meta 8, ao prever aumento da escolaridade da população, inclui como público-alvo

[...] segmentos populacionais que sofrem preconceitos e opressões em razão de sua nacionalidade, condição social e local de nascimento, raça, cor, religião, origem étnica, convicção política ou filosófica, deficiência física ou mental, doença, idade, atividade profissional, estado civil, classe social, sexo, orientação sexual e moral familiar respeitando-se a orientação dos pais e/ou responsáveis. (CEARÁ, 2016, Meta 8, grifos nossos).

Esta afırmação se repete nas estratégias que tratam da ampliação da oferta de Educação de Jovens e Adultos (EJA) e da formação inicial e continuada de professores, gestores e demais profissionais da educação (CEARÁ, 2016, Meta 8, Estratégias 8.3, 8.8). 0 documento também ressalta a importância de "possibilitar a inserção produtiva e autonomia econômica das mulheres”, destacando como estratégia a universalização da oferta de "Educação Infantil, a partir do 0 (zero) mês de idade, creches em período integral; Fundamental e Médio dentro das comunidades indígenas, quilombola e do campo, independentemente do número de alunos" (CEARÁ, 2016, Meta 21, Estratégia 21.1, grifos nossos). Essas referências evidenciam a presença das deliberações dos sete eixos da Conferência Nacional de Educação (CONAE), inclusive as do Eixo II "Educação e Diversidade: Justiça Social, Inclusão e Direitos Humanos” em consonância com os princípios do ensino estabelecidos na Lei de Diretrizes e Bases da Educação Nacional (BRASIL, 1996) que, de acordo com o Artigo $3^{\circ}$ da Constituição Federal de 1988, inclui entre os objetivos fundamentais da República Federativa do Brasil "promover o bem de todos, sem preconceitos de origem, raça, sexo, cor, idade e quaisquer outras formas de discriminação" (BRASIL, 1988/2001).

Vale notar, no entanto, que essas menções dividem espaço com o necessário controle e prerrogativa das famílias sobre a escola no tratamento destes temas, fazendo referência a uma suposta moral familiar. Para isso o plano prevê em suas estratégias, uma delas contida na Meta 7, o fomento da qualidade da educação básica em todas as etapas e modalidades, a "avaliação prévia e específica do material escolar, voltado 
para crianças e adolescentes, no mínimo, nos seguintes itens: racismo, preconceito, discriminação e orientação sexual" (CEARÁ, 2016, Meta 7, Estratégia 7.49, grifos nossos). Apesar de aparentemente contraditório, este plano de educação expressa a força de setores conservadores atuantes no poder Legislativo. No próprio texto, o veto é justificado com base no sintagma ${ }^{7}$ da "ideologia de gênero" -, com a finalidade de denunciar o suposto caráter doutrinário da abordagem de gênero na formação moral de crianças e adolescentes, criando um verdadeiro pânico nas famílias em relação a essa temática. Por isso, o controle da família é indispensável para evitar uma suposta dissolução dos papéis sociais de homens e mulheres e, consequentemente, da família nuclear.

Aqui fica evidente a forte conotação antifeminista e heteronormativa da retórica da "ideologia de gênero" em nome da defesa da família heterossexual como norma, do papel da mulher no centro do universo doméstico com a defesa do "conceito de "natureza humana' como decorrente de uma 'lei natural' dada por Deus, comprovada pela biologia e inalterável, o qual é peça fundamental na argumentação que sustenta a condenação do gênero qualificado como uma 'ideologia', com forte conotação negativa" (ROSADONUNES, 2015, p. 1250). A própria definição de família é sustentada por uma concepção biológica inalterável de homem e mulher e de reprodução. 0 uso essencialista da mulher, no singular ou no plural universal, pressupõe uma identidade feminina universal, com evidentes conotações biológicas e com forte intenção de produzir hierarquias que sustentem relações desiguais e de dominação no âmbito específico da família, também referida no singular e assim defendida pelo Vaticano desde a Conferência do Cairo.

\section{A omissão de qualquer menção ao gênero (GO, PE, SP)}

Como a maior parte dos estados, Goiás, Pernambuco e São Paulo assistiram a fortes protestos durante a votação nas assembleias legislativas, com influência do contexto antigênero que marcou a votação do PNE (BRASIL, 2014). 0 debate repercutiu nas várias assembleias legislativas nas quais os PEEs entraram em votação e dividiu opiniões aglutinando camadas populares referenciadas na igreja ou não.

Apesar das inúmeras tentativas de professores(as) e estudantes favoráveis à inclusão das questões de gênero e diversidade sexual nas escolas, os estados de Goiás, Pernambuco e São Paulo suprimiram toda e qualquer discussão relativa ao tema. Mencionam a importância de se desenvolver nas escolas ações que suscitem uma cultura de paz, com segurança e respeito aos direitos humanos, mas excluíram a palavra gênero, até mesmo gênero alimentício, e todas as expressões a ela relacionadas - mulher, homem, orientação sexual, sexualidade.

0 estado de São Paulo, em sua Meta 3 sobre elevação da escolaridade da população jovem, menciona o combate a "qualquer forma de discriminação" (SÃo PAULO, 2016, Meta 3, Estratégia 3.9, grifos nossos) e o estado de Goiás prevê a prevenção da "violência, o bullying, o uso e abuso de drogas" (GOIÁS, 2015, Meta 2, Estratégia 2.15, grifos nossos). Já Pernambuco acrescenta que o combate à violência deve vir acompanhado

7- A caracterização da "ideologia de gênero" enquanto um sintagma é feita por Rogério Junqueira (2017) para destacar sua falta de precisão conceitual e seu uso fortemente voltado para a criação do pânico moral. 
da "identificação e supressão de todas e quaisquer fontes diretas ou indiretas geradoras de racismo, discriminação, xenofobia e intolerâncias correlatas, inclusive nos currículos, práticas e materiais didático-pedagógicos" (PERNAMBUCO, 2015, Meta 8, Estratégia 8.10, grifos nossos), mas as menções à discriminação, à violência ou, no caso de Pernambuco, ao racismo, xenofobia e intolerâncias correlatas não aparecem relacionadas à perspectiva de gênero. 0 gênero é omitido completamente dos textos dos planos destes estados. Assistimos novamente à defesa do caráter velado da menção ao gênero quando se trata do plano nacional de educação atual, tendência apontada no início do século quando era preciso ler nas entrelinhas das políticas voltadas para a educação pública para ver, na defesa dos direitos em geral, pequenos avanços quanto às questões de gênero (VIANNA; UNBEHAUM, 2004).

Chama ainda a atenção a linguagem utilizada nestes planos categorizados pela omissão do gênero. Ao nomearem os indivíduos de ambos os sexos, os planos desse grupo enfatizam a forma masculina. Sabemos que, em nossa sociedade, o uso da palavra articulada ou escrita como meio de expressão e de comunicação tem no masculino genérico a forma utilizada para expressar ideias, sentimentos e referências a outras pessoas. Contudo, essa utilização nunca é neutra. A linguagem enquanto sistema de significação é expressão da cultura e das relações sociais de um determinado momento histórico. Se, por um lado, o masculino genérico empregado expressa uma forma comum de se manifestar, por outro, seu uso - especialmente em documentos que visam pautar as políticas públicas de educação por um período de dez anos - não é impune, pois a adoção exclusiva do masculino pode expressar discriminação sexista e reforçar o modelo linguístico androcêntrico. Tal androcentrismo não pode (nem deve) ser aceito como inquestionável ou como mera questão de norma linguística. Isso porque pode dar margem para ocultar as desigualdades de gênero. 0 reconhecimento dessas desigualdades é o primeiro passo para a sua supressão.

- uso parcial do gênero: direitos humanos, mulheres, cultura da paz (AP, AC, AL, ES, DF, PB, PI, PR, RN, RO, RS, SC, SE, TO)

Nestes catorze planos, a menção a questões de gênero aparece de forma genérica na menção aos direitos humanos ou com pautas de direitos específicos para as mulheres ou ainda com enaltecimentos à importância do respeito entre homens e mulheres e da cultura de paz nas escolas.

$\mathrm{Na}$ grande maioria, além da palavra gênero ser substituída por sexo e o par "homens e mulheres" ser reiterado ao longo de todo o texto, some qualquer referência à orientação sexual e à afirmação das identidades de gênero, prevalecendo os padrões cis-heteronormativos. Apenas no caso do Rio Grande do Sul e do Amapá o texto omite a palavra gênero, mas inclui menção a orientação sexual, apenas quando indica a "promoção dos princípios do respeito aos direitos humanos, à diversidade e à sustentabilidade socioambiental, à orientação sexual e às escolhas religiosas" (RIO GRANDE DO SUL, 2015, Art. $2^{\circ}$, Inciso X, grifos nossos) e na meta que trata da expansão das matrículas no ensino superior (AMAPÁ, 2015, Meta 15, Estratégia 15.5), mas sem maiores aprofundamentos. 
O PEE do Rio Grande do Norte (2016, Meta 1, grifos nossos) prevê “a implementação de ações de inclusão, objetivando a superação das desigualdades que atingem mulheres". Além delas há menções aos "indígenas, negros, quilombolas, povos tradicionais, povos do campo e pessoas com deficiência” (RIO GRANDE DO NORTE, 2016), mas não se fala em pessoas LGBT. A referência às mulheres aparece vinculada à luta por creches e educação infantil, assim como ao cuidado com as crianças, sem a explicitação dos direitos reprodutivos, bem como o direito à informação e suporte necessários para essa decisão. Alagoas vincula o incentivo à autonomia das mulheres à expansão da oferta de educação infantil. 0 estado prevê um "levantamento e publicação da demanda de creche, para população de 0 (zero) a 03 (três) anos, e de pré-escola, para crianças de 04 (quatro) e 05 (cinco) anos" (ALAG0AS, 2016, Meta 1, Estratégia 1.8, grifos nossos). Entre adolescentes e jovens do ensino fundamental a preocupação mais recorrente engloba um conjunto de situações: discriminação, preconceitos, violência e gravidez precoce.

Espírito Santo (2015, Meta 3, Estratégia 3.8), Pará (2015, Estratégia 3.8), Rio Grande do Norte (2016, Meta 3, Estratégia 10), Piauí (2015, Meta 3, Estratégias 3.19 e 3.21), Sergipe (2015, Meta 3, Estratégia 3.9) e Tocantins (2015, Meta 4, Estratégia 4.12) incluem o conjunto dessas situações como alvo de acompanhamento para a permanência de estudantes beneficiárias de programas de transferência de renda no ensino médio.

No âmbito do ensino superior, o olhar volta-se para as políticas de inclusão e assistência estudantil para as mulheres nesse nível de ensino (PARANÁ, 2015, Meta 12, Estratégia 12.6) ou até mesmo nos cursos de pós-graduação, nos quais a proposta é "estimular a participação das mulheres em cursos de pós-graduação stricto sensu, em particular naqueles ligados às áreas de Engenharia, Matemática, Física, Química, Informática e outros no campo das ciências" (DISTRITO FEDERAL, 2015, Meta 14, Estratégia 14.5; ALAGOAS, 2016, Meta 14, Estratégia 14.8, grifos nossos).

Outro tema reiterado pela maioria dos planos desse grupo é a referência à violência doméstica e sexual, mas não se vê menção a gênero ou orientação sexual. Esse formato aparece nos PEE do Acre, Alagoas, Amapá, Amazonas, Ceará, Maranhão, Paraíba, Paraná, Santa Catarina e Sergipe com textos que expressam a necessidade de "garantir políticas de combate à violência na escola e no seu entorno, inclusive pelo desenvolvimento de ações destinadas à capacitação de educadores para detecção dos sinais de suas causas, como a violência doméstica e sexual, favorecendo a adoção das providências adequadas que promovam a construção da cultura de paz e um ambiente escolar dotado de segurança para a comunidade" (Acre, 2015, Meta 7, Estratégia 7.17; ALAGOAS, 2015, Meta 7, Estratégia 7.43; AMAPÁ, 2015, Meta 4, Estratégia 4.6; AMAZONAS, 2015, Meta 7, Estratégia 7.18; CEARÁ; 2016, Meta 7, Estratégia 7.20; MARANHÃ0, 2014, Meta 8, Estratégia 8.24; PARAÍBA, 2015, Meta 19, Estratégia 19.23; PARANÁ, 2015, Meta 7, Estratégia 7.22; SANTA CATARINA, 2015, Meta 7, Estratégia 7.18; SERGIPE, 2015, Meta 7, Estratégia 7.22, grifos nossos).

Nesse conjunto temos uma exceção com o texto mais enxuto do estado do Rio Grande do Norte (2016, Dimensão 8, Meta 1, Estratégia 10, grifos nossos), que menciona apenas o desenvolvimento de "ações fundamentadas em direitos humanos sobre a prevenção às drogas e da violência com relação às mulheres, criança e jovens, no contexto escolar”. 
A defesa do respeito também é mencionada por alguns planos. 0 PEE do Rio Grande do Norte é bem amplo e refere-se a toda forma de preconceito e garante a inclusão nos currículos escolares das "especificidades e necessidades formativas da Educação de Jovens e Adultos, da infância, da adolescência, dos povos do campo, das águas e comunidades ciganas", com ênfase "na perspectiva dos direitos humanos, adotando práticas de superação do racismo, do machismo, do sexismo, e de toda forma de preconceito, contribuindo para a efetivação de uma educação não discriminatória" (RIO GRANDE DO NORTE, 2016, Dimensão 8, Meta 1, Item 4, grifos nossos).

As diretrizes do plano do Distrito Federal (2015, Art. 2º Inciso XI, grifos nossos) fazem uma referência muito genérica para incluir a "promoção dos princípios do respeito aos direitos humanos". De modo semelhante, o estado de Tocantins (2015, Meta 11, Incisos I, II, III, grifos nossos) inclui três incisos sobre direitos humanos, todos eles na meta que trata da educação ambiental. Apesar de estarem situados em uma meta específica, tratam de temas gerais como "implementação de políticas e programas educacionais para a educação em direitos humanos, com vistas a assegurar os direitos individuais e coletivos, a cidadania e o respeito às diferenças"; "currículo escolar que atenda a educação em direitos humanos, em todas as etapas e modalidades da educação básica, de forma permanente e articulada, a partir dos processos pedagógicos, transversais e interdisciplinares”.

0 PEE do Paraná (2015, Meta 2, Estratégia 2.21 grifos nossos) enfatiza “a educação que efetive o respeito entre homens e mulheres" quando trata do currículo e da formação inicial continuada profissionais da educação (PARANÁ, 2015, Meta 1, Estratégia 1.3; Meta 15, Estratégia 15.11).

Nesse conjunto de planos, a menção ao respeito vem sempre acompanhada de uma ressalva: a precedência da família sobre o Estado. São muitas as formas de afırmação dessa precedência, como por exemplo nas diretrizes do plano do Distrito Federal que inclui a "promoção dos princípios do respeito aos direitos humanos", mas com um condicionante que lhe submete às "convicções morais dos estudantes e de seus pais ou responsáveis" (DISTRITO FEDERAL, 2015, Art. $2^{\circ}$, Inciso XI, grifos nossos). Ou então, no caso do PEE do Paraná que atenta para as "especificidades da faixa etária" (2015, Meta 1, Estratégia 1.3; Meta 2, Estratégia 2.21; Meta 15, 15.11, grifos nossos), e do "reconhecimento da precedência da família na educação escolar até o término do ensino médio, fortalecendo e tornando efetiva a participação dos pais/mães nas politicas pedagógicas que tratem do assunto" (TOCANTINS, 2016, Art. 2º, Inciso XII, grifos nossos).

A perspectiva de gênero nesses estados é restrita e retoma uma abordagem muito próxima do enfoque velado de gênero característico do texto da Constituição Federal (BRASIL, 1988/2001) diluindo as questões de gênero na grande chave dos direitos humanos, da cultura da paz e do respeito entre homens e mulheres, sem nenhuma menção específica às múltiplas desigualdades que esses termos podem conter, como se seus significados fossem autoevidentes. Ainda que alguns planos deem também destaque para as denúncias contra o machismo, o sexismo e, em especial, a violência sexual e doméstica contra mulheres e em caso de denúncia contra a violência infantil, trata-se de proposições soltas, por não estarem vinculadas explicitamente a uma abordagem determinada, podem ser materializadas tanto em articulação com questões de gênero e sexualidade, quanto 
dentro de uma perspectiva conservadora e restrita aos corpos biológicos e naturalizados de homens e mulheres.

Além disso, essa menção aos direitos humanos e/ou ao respeito entre homens e mulheres, à exceção da breve referência à orientação sexual no Rio Grande do Sul, omite qualquer alusão às pessoas LGBT, o que parece ser alvo de maior preocupação, investimento reacionário e um dos principais objetos de disputa política.

Rondônia é um caso exemplar. 0 plano inicialmente aprovado contava com diversas referências às questões LGBT, de orientação sexual e identidade de gênero. A partir de uma lei aprovada posteriormente, todas as citações às questões LGBT foram retiradas. 0 alvo da lei subsequente foi justamente o conjunto de itens em que essa pauta era citada, mas sobreviveram todas as menções à promoção do direito das mulheres, visando garantir "a partir da data de vigência do plano, em 100\% das escolas, ações preventivas dentro do currículo escolar sobre gravidez na adolescência” (RONDÔNIA, 2015, Meta 2, Item 2.21, grifos nossos) e garantir "politicas de combate à violência na escola, inclusive pelo desenvolvimento de ações destinadas à capacitação de educadores para a detecção dos sinais de suas causas, como a violência doméstica e sexual" (RONDÔNIA, 2015, Meta 7, Item 7.12, grifos nossos).

Assim, neste grupo, o modo de abordagem dos direitos humanos, dos direitos à educação, da própria violência doméstica e sexual contra mulheres não incorpora as relações de gênero nas políticas de educação, mais especificamente nos planos de educação examinados, o gênero aparece velado no tratamento do tema. Isso indica que, apesar de fazer referência ao machismo, ao sexismo ou à violência doméstica, os planos reafirmam uma abordagem generalista, aproximando-se da mesma tendência do PNE. Mais do que isso, esse grupo indica um grande retrocesso ao tomar gênero como sinônimo de mulher ou mulheres. Retoma-se o uso essencialista da expressão mulher, amplamente criticada por várias feministas quando ao conceito de gênero caberia exatamente a tarefa de problematizar essa concepção. Nesse conjunto prevalece o que Judith Butler (1990, 2014) denomina de matriz heterossexual, ou seja, falar de homem, mulher e família nas proposições contidas nestes planos é falar da imposição da heterossexualidade como padrão.

\section{A explicitação do gênero como direitos humanos:} mulheres, pessoas LGBT (AM, BA, MA, MT, MTS, PA, RR)

Esse grupo de sete estados apresenta uma incorporação detalhada e bastante ampla da perspectiva de gênero e do reconhecimento das sexualidades como integrantes da função social da educação e, portanto, a ser prevista nas leis que organizam as políticas relativas ao acesso e permanência nos vários níveis e modalidades de ensino - incluindo educação infantil, ensino fundamental e médio, além da educação de jovens e adultos, chegando até ao ensino superior em alguns estados - e nas diretrizes educacionais, no conteúdo do próprio currículo escolar e na formação inicial e/ou continuada de professores.

Quanto às questões relativas ao acesso e à permanência nos vários níveis e modalidades de ensino, para universalizar o "atendimento escolar para toda a população de 15 a 17 anos”, o estado do Amazonas propõe a implementação de políticas de "prevenção 
à evasão, abandono escolar" motivadas por qualquer "preconceito ou discriminações sociais, sexuais, religiosas, culturais e etnorraciais” (AMAZONAS, 2015, Meta 3, Estratégia 3.11, grifos nossos). Portanto, apesar de mencionar os termos evasão e abandono deixa claro que a desistência dos estudos está relacionada com as condições advindas das desigualdades sociais, sejam elas de classe, etnorraciais, de gênero etc.

0 Mato Grosso caminha na mesma direção e propõe como meta o estabelecimento de "politicas de ações afirmativas a partir de pesquisas, junto ao censo escolar sobre reprovação, evasão/abandono escolar, fazendo um recorte de gênero, cor/raça, renda e nível de escolaridade dos pais" (MATO GROSSO, 2014, Meta 15, Estratégia 1, grifos nossos). 0 referido estado também recomenda adotar "medidas administrativas, pedagógicas e organizacionais necessárias para garantir ao estudante o acesso e a permanência na escola sem discriminação por motivo de identidade de gênero e orientação sexual" (MAT0 GROSSO, 2014, Meta 2, Estratégia 33, grifos nossos).

Já Roraima tem entre suas estratégias para garantia de acesso e permanência ao ensino superior "assegurar programas de ação afirmativa para pessoas com deficiências, negros, indígenas, povos das águas e da floresta, de diferentes orientações sexuais" (RORAIMA, 2015, Item 5, Estratégia 8, grifos nossos). 0 estado do Maranhão é bastante enfático e prevê políticas para a garantia de "acesso e condições para permanência" para "gays, lésbicas, bissexuais, travestis e transexuais no Ensino Fundamental” (MARANHÃ0, 2014, Meta 2, Estratégia 2.17, grifos nossos).

Em um país onde a expectativa de vida de uma pessoa trans é de 35 anos de idade e não se tem registros sistematizados sobre o exercício de seus direitos à educação formal (MOTT, MICHELS, 2018), medidas como essa, ao quebrarem o silêncio, trazem à tona direitos ainda não exercidos, sinalizando para possíveis mudanças, como define Ball (1989).

Ainda no que diz respeito à garantia de acesso, permanência e aproveitamento escolar, o PEE de Mato Grosso prevê o cuidado com o que denomina "gravidez precoce" no caso de "jovens beneficiárias de programas de transferência de renda, no ensino médio" (MATO GROSSO, 2014, Meta 9, Estratégia 12, grifos nossos). Muitos estudos questionam a dita precocidade da gravidez entre jovens e adolescentes sublinhando que são muitos os elementos utilizados pelas jovens para concretizar ou adiar a maternidade (OLIVEIRA, 2007), mas aqui vale destacar a importância de o plano ressaltar a responsabilidade da escola na garantia da continuidade dos estudos destas jovens.

Alguns planos falam explicitamente da inclusão de questões de gênero e da sexualidade no currículo. E novamente o PEE do Maranhão se destaca ao prever apoio para “as Secretarias Municipais de Educação na elaboração, na implantação, na implementação e avaliação de propostas curriculares para a Educação Infantil" que respeitem a "diversidade de gênero" (MARANHÃ0, 2014, Meta 1, Estratégia 1.17, grifos nossos), indicando que "todas as políticas públicas da diversidade", entre elas as voltadas para a "garantia de direitos aos/as negros/as, indígenas, mulheres, pessoas do segmento LGBTTT e outros" sejam "inseridas nos Projetos Político-pedagógicos das escolas estaduais" (MARANHÃ0, 2014, Meta 7, Estratégia 7.8, grifos nossos).

0 plano do estado do Amazonas é ainda mais específico ao prever para o ensino médio "currículos escolares que organizem, de maneira flexível e diversificada, conteúdos 
obrigatórios e eletivos articulados em dimensões como ciência, trabalho, linguagens, tecnologia, cultura, esporte, educação para o trânsito e educação sexual" (AMAZONAS, 2015, Meta 3, Estratégia 3.1, grifos nossos).

0 PEE de Mato Grosso indica como uma das estratégias para aferir educação de qualidade "assegurar o desenvolvimento de projetos curriculares articulados com a base nacional comum" e relacionados, entre outros aspectos, aos "direitos humanos, gêneros, sexualidade" (MATO GROSSO, 2014, Meta 2, Estratégia 13, grifos nossos). O PEE prevê ainda a elaboração de "diretrizes que orientem os sistemas de ensino na implementação de ações que comprovem o respeito ao cidadão e à não discriminação por orientação sexual" (MATO GROSSO, 2014, Meta 2, Estratégia 34, grifos nossos).

Sobre o material pedagógico, os estados de Maranhão (2014, Meta 7, Estratégias 7.11 e 7.15), Mato Grosso do Sul (2014, Meta 7, Estratégia 7.35) e Pará (2015, Meta 7, Estratégia 7.34) propõem a aquisição, produção e distribuição de material didático sobre direitos humanos, prevenção a DST/Aids e questões de gênero, orientação sexual e sexualidade para profissionais da educação, estudantes, pais e/ou responsáveis. Na produção de material pedagógico o PEE do Maranhão (2014, Meta 7, Estratégia 7.11, grifos nossos) fala explicitamente em "relações de gênero" e "diversidade sexual".

Estes estados reconhecem que não basta prever a inclusão das questões de gênero e produção das sexualidades nos currículos e materiais didáticos, dando ênfase à importância da formação inicial e continuada de professores e professoras. Mato Grosso do Sul (2014, Meta 7, Estratégia 7.34) e Pará (2015, Meta 7, Estratégia 7.34) preveem formação continuada sobre "direitos humanos", "prevenção das DST/Aids, alcoolismo e drogas, em sua interface com as questões de gênero e sexualidade, questões étnicoraciais, geracionais, situação das pessoas com deficiência”, com textos idênticos. 0 PEE de Mato Grosso do Sul prevê ainda a articulação com "instituições de ensino superior, públicas e privadas a oferta, na sede e/ou fora dela, de cursos de formação continuada" sobre “educação e gênero" (MATO GROSSO DO SUL, 2014, Meta 16, Estratégia 16.2, grifos nossos). O PEE da Bahia (2016, Meta 15, Estratégia 15.15, grifos nossos) acrescenta a formação inicial de professores/as de modo a

[...] assegurar que as questões de diversidade cultural, étnica, religiosa e sexual sejam tratadas como temáticas nos currículos [...] sob égide do Plano Nacional de Educação em Direitos Humanos e das Diretrizes Nacionais para a Educação em Direitos Humanos emanadas pelo Conselho Nacional de Educação.

No PEE de Mato Grosso (2014, Meta 5, Estratégia 16, grifos nossos), a referência é mais extensa e indica oferta de "formação específica inicial e continuada" aos profissionais de educação "referente a gênero, sexualidade e orientação sexual, dentro do segmento diversidade, visando o enfrentamento do sexismo e da homofobia/lesbofobia/transfobia na perspectiva dos direitos humanos".

Mato Grosso do Sul e Pará possuem textos idênticos que preveem também que a implementação de políticas de "prevenção e combate à violência nas escolas" devem incluir além da "violência doméstica e sexual" - prevista pela ampla maioria dos estados 
como veremos adiante - as violências por "questões de gênero e de orientação sexual", inclusive com "com capacitação dos profissionais da educação para atuarem em ações preventivas junto aos (às) estudantes na detecção das causas”. (Mato Grosso do Sul, 2014, Meta 7, Estratégia 7.33; PARÁ, 2015, Meta 7, Estratégia 7.33, grifos nossos).

Os órgãos de políticas para mulheres são citados em três planos desse grupo. 0 Maranhão (2014, Meta 7, Estratégia 7.3) propõe, de forma geral, o estabelecimento de parcerias com "Secretaria Estadual de Direitos Humanos, Secretaria Estadual de Igualdade Racial, Secretaria Estadual da Mulher”, enquanto o Mato Grosso do Sul (2014, Meta 3, Estratégia 3.74) indica parcerias com órgãos como

[...] Secretaria de Assistência Social - SEDSS; Centro de Referência da Assistência Social - CRAS; Ministério Público Estadual - MPE; Secretaria de Políticas para as Mulheres - SEPMULHERES; Secretaria de Justiça e Direitos Humanos - SEJUDH; Secretaria de Humanização; Secretaria de Estado de Saúde - SESACRE de promoção dos direitos das mulheres para o combate ao preconceito, à violência e qualquer forma de discriminação.

0 PEE do Mato Grosso (2014, Meta 15, Estratégia 5) indica o apoio aos "projetos inovadores que visem o desenvolvimento de propostas pedagógicas adequadas às necessidades específicas dos estudantes quanto ao conhecimento das diversidades étnicoracial, de gênero, sexualidade e orientação sexual”.

Mas o Maranhão é o único estado que prevê a implantação na Secretaria de Estado da Educação e em todas as Unidades Regionais de Educação de "um setor ou equipe técnica especializada e multidisplinar" para "realizar, acompanhar, avaliar e monitorar as atividades referentes à educação em direitos humanos, à educação para as relações étnicoraciais, para as relações de gênero, identidade de gênero e diversidade sexual", fortalecendo "parcerias entre organismos públicos, não governamentais e com os movimentos sociais', entre eles "de mulheres, feministas e LGBTTT" com o objetivo de "alcançar uma educação não discriminatória, não sexista, não machista, não racista, não homofóbica, não lesbofóbica, não transfóbica" (MARANHÃO, 2014, Meta 7, Estratégia 7.7, grifos nossos).

Coerentes com os fundamentos e princípios da Constituição Federal, esses documentos evidenciam zelo e cuidado com muitos dos aspectos relativos aos significados e às implicações de gênero nas relações e nos conteúdos escolares, reconhecendo-as como referências fundamentais para a constituição da identidade de crianças e jovens.

Mesmo com especificidades, cada um dos planos desse grupo problematiza o caráter fixo e binário da oposição entre significados masculinos e femininos ao incluírem o combate ao sexismo, ao machismo e à LGBTfobia conceito que denuncia "uma forma de inferiorização, consequência direta da hierarquia das sexualidades, assim como confere à heterossexualidade um status superior, situando-a no patamar do que é natural, do evidente" (Borrillo, 2001, p. 15). Ou seja, a agenda de gênero é explícita nestes planos ao acolher as demandas do ativismo LGBT - e em muitos momentos lado a lado com as demandas feministas e dos movimentos de mulheres - percebida nas referências à violência sexual, à diversidade sexual, à orientação sexual e à identidade de gênero, assim como na previsão do combate à LGBTfobia. Questiona-se, deste modo, a tendência de pensar as identidades sexuais como dadas, como básicas e universais. Pode-se, portanto, apreender 
que esse conjunto de planos traz uma crítica mais incisiva às características tidas pela tradição como naturalmente masculinas ou femininas e às afirmações biológicas sobre corpos, comportamentos e habilidades de mulheres e homens e sobre diferenças sociais, destacando o caráter socialmente construído do conhecimento científico.

Essas menções nos ajudam a perceber nossas conquistas e atentar para o fato de que foram, paulatinamente, desafiadas e desconstruídas as concepções essencialistas sustentadas tanto no determinismo biológico quanto no discurso religioso cristão que (ainda) pautam as noções de mulher, mãe, homem, professora, professor, criança, infância, juventude, corpo, sexualidade e família.

\section{Conclusões inconclusas}

Se há algo que podemos reter nessa e em outras pesquisas recentes por nós desenvolvidas é que o lugar do gênero e da produção das sexualidades nas políticas de educação é um lugar ainda por se consolidar. É, portanto, objeto de disputa cujo processo inconcluso, necessariamente em aberto, está permeável às diferentes concepções de educação, de direito ao acesso, à permanência, ao conteúdo específico com profissionais qualificados para tal.

Os distintos sentidos dos princípios de universalização, expansão e democratização do acesso à educação presentes em todos os planos de educação examinados evidenciam a disputa em torno da possível interação entre gênero e condições de aprendizagem, trabalho docente, financiamento adequado, reconhecimento, valorização das diferenças no direito à educação. 0 texto da lei e suas entrelinhas nos ajudam a compreender a potencialidade (ou não) das relações de gênero e da produção das sexualidades em cada um dos planos de educação.

0 próprio conceito e uso do gênero também está em disputa. Ou seja, apesar do alarde e do impacto provocados pela supressão da menção direta ao gênero no Plano Nacional de Educação, mais da metade dos planos de educação, ainda que de formas bastante distintas, inseriu questões relativas à agenda das mulheres, sob uma perspectiva de gênero, na sua redação final. Vários estados comprometem-se com o enfrentamento das discriminações sociais em geral e alguns com o acolhimento de várias dimensões do gênero e da diversidade sexual em distintos níveis e modalidades de ensino como na educação infantil, na educação básica, outros estados incluem o ensino médio e a educação de jovens e pessoas adultas, e alguns até o ensino superior e a pós-graduação.

Quase um terço dos planos expressam claramente que a garantia de acesso e permanência com qualidade passa pelo enfrentamento das desigualdades de gênero nas medidas administrativas, pedagógicas e organizacionais, abrangendo desde a prevenção das chamadas Infecções Sexualmente Transmissíveis (ISTs) e da Síndrome da Imunodeficiência Adquirida (Aids), das violências sexuais, de gênero e por orientação sexual até a inserção do gênero e da sexualidade no currículo, nos materiais pedagógicos e na formação inicial e continuada de professores e professoras, envolvendo profissionais da educação, estudantes, pais, mães e responsáveis no confronto do sexismo e da LGBTfobia. Em alguns planos com o apoio de órgãos de políticas para as mulheres e até uma equipe especializada e multidisciplinar. 
Podemos supor que esse movimento de afirmação é fruto das inúmeras conquistas das mulheres, das pessoas LGBT já registradas no início deste artigo. E, nos planos que explicitam as várias facetas da inserção de gênero nesta política de educação, este adquire caráter relacional, capaz de abarcar a estruturação das relações sociais, englobando as dimensões de classe, raça, etnia e geração na procura de apreensão das distintas formas de desigualdade.

Por outro lado, o discurso antigênero e a disputa pela aprovação de pautas conservadoras ficam manifestas na omissão do termo gênero e de todas as palavras a ele relacionadas, tais como mulher, homem, orientação sexual, sexualidade. Assim como no corte e/ou limitação da agenda LGBT em vários planos e no veto ao trabalho com gênero e sexualidade nas escolas sob o argumento de que a "ideologia de gênero" seria nefasta para a educação de crianças e jovens.

Em consonância com as várias pesquisas sobre o tema, já citadas, podemos afirmar que a retórica da "ideologia de gênero" tornou-se - também na elaboração dos planos de educação - uma chave de articulação ao redor da qual uma série de grupos e sujeitos aglutinaram-se com estratégias declaradamente contrárias ao avanço de qualquer política associada à agenda feminista e LGBT, além de reiterar, inclusive no texto da lei, uma perspectiva essencialista, determinista, cis-heteronormativa e masculinista.

A agenda reacionária fez-se ao mesmo tempo explícita na inserção de itens que restringem ou subjugam a abordagem destes temas na escola à concordância das famílias. A visão de que o gênero possa ser uma ameaça às crianças e suas famílias e o uso do conceito nas escolas uma interferência do Estado na soberania de pais e mães quanto à educação moral de seus filhos(as) sustenta tanto a ausência de menção ao tema, quanto o veto do uso do gênero nas escolas e seu controle pela família no sentido de evitar um suposto projeto de doutrinação ideológica que estaria sendo posto em curso por ativistas, educadores(as) e grupos políticos.

Ainda assim, o avanço conservador, ao menos no momento em que estes planos foram votados, contrapõe-se à manutenção de várias conquistas. Se um estado proíbe e mais outras três unidades da federação excluem nominalmente menções ao gênero e a quaisquer termos relacionados ao conceito e inserem itens que podem ser interpretados como restrições veementes ao debate livre destes temas, temos, por outro lado, um conjunto de sete estados que levam às últimas consequências a inserção do gênero e da produção das sexualidades em seus planos de educação.

De tal modo, se o lugar do gênero e da produção das sexualidades nunca existiu de fato, é possível afırmar que são "precisamente seus significados particulares que necessitam ser extraídos dos materiais que examinamos” (SCOTT, 2011, p. 101).

Permanecem, portanto, as contradições nas disputas de poder pela contribuição do gênero na função social da educação e, se assim for, importa saber que não se trata da simples polarização contra ou a favor do gênero. 0 que está proposto pelos documentos também será tensionado nas relações dos planos estaduais e distrital com os poderes locais e destes com cada uma das instâncias do sistema educacional e suas respectivas escolas com ações para impedir que estabelecimentos de educação abordem o tema nas salas de aula, assim como ações para manter a temática. 
Logo, mesmo marcado pela polarização própria do contexto atual com a retórica da ideologia de gênero que permeou a votação dos PEE entre 2014 e 2016, eles revelam pautas conflitantes, próprias da disputa de projetos distintos e até mesmo antagônicos.

Mas essa é apenas uma face da história que estamos por escrever, não existe um único projeto de educação e, sim, acirrada disputa. Trata-se de um cenário que exige a percepção das fissuras e das tensões, porque elas são muito importantes para a luta por manutenção de direitos.

\section{Referências}

ACRE. Decreto de Lei n 2.965, de 2 de julho de 2015. Aprova o Plano Estadual de Educação (PEE-AC) e dá outras providências. Rio Branco: Governo, 2015.

ALAGOAS. Decreto de Lei $\mathbf{n}^{0}$ 7.795, de 22 de janeiro de 2016. Aprova o Plano Estadual de Educação (PEE$\mathrm{AL})$ e dá outras providências. Maceió: Governo, 2016.

AMAPÁ. Decreto de Lei no 1.907, de 24 de junho de 2015. Aprova o Plano Estadual de Educação (PEE-AP) e dá outras providências. Macapá: Governo, 2015.

AMAZONAS. Decreto de Lei no 4.183, de 28 de junho de 2015. Aprova o Plano Estadual de Educação (PEEAM) e dá outras providências. Manaus: Governo, 2015.

ANDRADE, Teresa Cristina Bruno. Dos temas transversais à apropriação/vivência de valores: uma proposta de qualidade socioeducacional. 2004. Dissertação (Mestrado em Educação) - Faculdade de Filosofia e Ciências, Universidade Estadual Paulista "Júlio de Mesquita Filho", Marília, 2004.

BAHIA. Decreto de Lei n ${ }^{13.559}$, de 11 de maio de 2016. Aprova o Plano Estadual de Educação (PEE-BA) e dá outras providências. Salvador: Governo, 2016.

BALL, Stephen J. La micropolítica de la escuela: hacia una teoría de la organización escolar. Barcelona: Paidós, 1989.

BARBOUR, Rosaline. Grupos focais. Porto Alegre: Artmed, 2009.

BORRILLO, Daniel. Homofobia. Barcelona: Bellaterra, 2001.

BRASIL. Constituição da República Federativa do Brasil. Brasília, DF: Senado, 1988/2001.

BRASIL. Decreto de Lei no 13.005, de 25 de junho de 2014. Aprova o Plano Nacional de Educação (PNE) e dá outras providências. Diário Oficial da União, Brasília, DF, n. 120-A, p. 01, 26 jun. 2014.

BRASIL. Lei n. 9.394, de 20 de dezembro de 1996. Estabelece as Diretrizes e Bases da Educação Nacional. Diário Oficial da União, Brasília, DF, v. 134, n. 248, 23 dez. 1996.

BUTLER, Judith. Gender trouble: feminism and the subversion of identity. New York; London: Routledge; Champman \& Hall, 1990. 
BUTLER, Judith. Hablando claro, contestando: o feminismo crítico de Joan Scott. Rey Desnudo - Revista de Livros, Buenos Aires, v. 2, n. 4, p. 31-72, 2014.

CARREIRA, Denise. Igualdade e diferenças nas políticas educacionais: a agenda das diversidades nos governos Lula e Dilma. 2015. Tese (Doutorado em Educação) - Faculdade de Educação, Universidade de São Paulo, São Paulo, 2015.

CASTELLS, Manuel. Ruptura: la crisis de la democracia liberal. Madrid: Alianza, 2017.

CEARÁ. Decreto de Lei ${ }^{\circ} \mathbf{1 6 . 0 2 5}$, de 30 de maio de 2016. Aprova o Plano Estadual de Educação (PEE-CE) e dá outras providências. Fortaleza: Governo, 2016.

CONGREGAÇÃO PARA A DOUTRINA DA FÉ. Carta aos Bispos da Igreja Católica sobre a colaboração do homem e da mulher na Igreja e no mundo. Vaticano: [s. n.], 2004. Disponível em: <http://www.vatican.va/ roman_curia/congregations/cfaith/documents/rc_con_cfaith_doc_20040731_collaboration_po.html>. Acesso em: 18 set. 2018.

CORNEJO-VALLE, Mónica; PICHARDO, J. Ignacio. La "ideología de género" frente a los derechos sexuales y reproductivos: el escenario español. Cadernos Pagu, Campinas, n. 50, e175009, 2017.

CORRÊA, Sônia. A "política do gênero": um comentário genealógico. Cadernos Pagu, Campinas, n. 53, e185301, 2018.

CUNHA, Luiz Antônio. As agências financeiras internacionais e a reforma brasileira do ensino técnico: a crítica da crítica. In: ZIBAS, Dagmar M. L.; AGUIAR, Márcia Ângela. S.; BUENO, Maria Sylvia Simões (Org.). 0 ensino médio e a reforma da educação básica. Brasília, DF: Plano, 2002. p. 103-134.

DESLANDES, Keila. Formação de professores e direitos humanos: construindo escolas promotoras da igualdade. Belo Horizonte: Autêntica, 2016.

Distrito Federal. Decreto de Lei nº 5.499, de 14 de julho de 2015. Aprova o Plano Distrital de Educação (PDE) e dá outras providências. Brasília, DF: Governo, 2015.

ESPÍRITO SANTO. Decreto de Lei no 10.382, de 25 de julho de 2015. Aprova o Plano Estadual de Educação (PEE-ES) e dá outras providências. Vitória: Governo, 2015.

FERNANDES, Felipe Bruno Martins. Agenda anti-homofobia na educação brasileira (2003-2010). 2011. Tese (Doutorado em Ciências Humanas) - Centro de Filosofia e Ciências Humanas, Universidade Federal de Santa Catarina, Florianópolis, 2011.

FRIGOTTO, Gaudêncio (Org.). Escola "Sem" Partido: esfinge que ameaça a educação e a sociedade brasileira. Rio de Janeiro: LPP/UERJ, 2017.

GOIÁS. Decreto de Lei n 18.969 , de 22 de julho de 2015. Aprova o Plano Estadual de Educação (PEE-GO) e dá outras providências. Goiânia: Governo, 2015. 
JOÃO PAULO II. Léxicon de termos ambíguos e discutidos sobre a vida familiar e ética. Vaticano: [S. n.], 2003.

JUNQUEIRA, Rogério Diniz. "Ideologia de gênero": a gênese de uma categoria política reacionária ou: a promoção dos direitos humanos se tornou uma "ameaça à família natural"? In: RIBEIR0, Paula Regina Costa; MAGALHÃES, Joanalira Corpes (Org.). Debates contemporâneos sobre educação para a sexualidade. Rio Grande: FURG, 2017. p. 25-52.

LOURO, Guacira Lopes. 0 corpo educado: pedagogias da sexualidade. Belo Horizonte: Autêntica, 1999.

LOURO, Guacira Lopes. Um corpo estranho: ensaio sobre sexualidade e teoria queer. Belo Horizonte: Autêntica, 2006.

LUNA, Naara. A criminalização da "ideologia de gênero": uma análise do debate sobre diversidade sexual na Câmara dos Deputados em 2015. Cadernos Pagu, Campinas, v. 50, 2017.

MARANHÃO. Decreto de Lei nº10.099, de 11 de junho de 2014. Aprova o Plano Estadual de Educação (PEEMA) e dá outras providências. São Luís: Governo, 2014.

MATO GROSSO. Decreto de Lei n 10.111, de 06 de junho de 2014. Aprova o Plano Estadual de Educação (PEE-MS) e dá outras providências. Cuiabá: Governo, 2014.

MATO GROSSO DO SUL. Decreto de Lei no 4.621, de 22 de dezembro de 2014. Aprova o Plano Estadual de Educação (PEE-MS) e dá outras providências. Campo Grande: Governo, 2014.

MOTT, Luiz; MICHELS, Eduardo. Mortes violentas de LGBT no Brasil relatório - 2017. Salvador: Grupo Gay da Bahia, 2018.

OLIVEIRA, Elisabete Regina Baptista de. Sexualidade, maternidade e gênero: experiências de socialização de mulheres jovens de estratos populares. 2007. Dissertação (Metrado em Educação) - Faculdade de Educação, Universidade de São Paulo, São Paulo, 2007.

PARÁ. Decreto de Lei no 8.186, de 23 de junho de 2015. Aprova o Plano Estadual de Educação (PEE-PA) e dá outras providências. Belém: Governo, 2015.

PARAÍBA. Decreto de Lei nº 10.488, de 23 de junho de 2015. Aprova o Plano Estadual de Educação (PEE-PB) e dá outras providências. João Pessoa: Governo, 2015.

PARANÁ. Decreto de Lei no 18.492, de 24 de junho de 2015. Aprova o Plano Estadual de Educação (PEE-PR) e dá outras providências. Curitiba: Governo, 2015.

PERNAMBUCO. Decreto de Lei n $^{\text {15.533, de }} 23$ de junho de 2015. Aprova o Plano Estadual de Educação (PEE-PE) e dá outras providências. Recife: Governo, 2015.

PIAUÍ. Decreto de Lei n 6.733, de 17 de dezembro de 2015. Aprova o Plano Estadual de Educação (PEE-PE) e dá outras providências. Teresina: Governo, 2015. 
PRAD0, Marco Aurélio Maximo; CORRÊA Sonia. Retratos transnacionais e nacionais das cruzadas antigênero. Psicologia Política, São Paulo, v. 18, n. 43, p. 444-448, 2018.

REIS, Toni; EGGERT, Edla. Ideologia de gênero: uma falácia construída sobre os Planos de Educação Brasileiros. Educação \& Sociedade, Campinas, v. 38, n. 138, p. 9-26, jan./mar, 2017.

RIO GRANDE DO NORTE. Decreto de Lei $\mathbf{n}^{\circ}$ 10.049, de 27 de janeiro de 2016. Aprova o Plano Estadual de Educação (PEE-RN) e dá outras providências. Natal: Governo, 2016.

RIO GRANDE DO SUL. Decreto de Lei $n^{0}$ 14.705, de 25 de junho de 2015. Aprova o Plano Estadual de Educação (PEE-RS) e dá outras providências. Porto Alegre: Governo, 2015.

RONDÔNIA. Decreto de Lei n 3.565, de 3 de junho de 2015. Aprova o Plano Estadual de Educação (PEE-R0) e dá outras providências. Porto Velho: Governo, 2015.

RORAIMA. Decreto de Lei n 1.008, de 3 de setembro de 2015. Aprova o Plano Estadual de Educação (PEERR) e dá outras providências. Boa Vista: Governo, 2015.

ROSADO-NUNES, Maria José Fontelas. A "ideologia de gênero" na discussão do PNE: a intervenção da hierarquia católica. Horizonte, Belo Horizonte, v. 13, n. 39, p. 1237-1260, jul./set. 2015.

SANTA CATARINA. Decreto de Lei $\mathrm{n}^{0} \mathbf{1 6 . 7 9 4}$, de 14 de dezembro de 2015. Aprova o Plano Estadual de Educação (PEE-SC) e dá outras providências. Florianópolis: Governo, 2015.

SÃO PAULO (Estado). Decreto de Lei n 16.279, de 8 de julho de 2016. Aprova o Plano Estadual de Educação (PEE-SP) e dá outras providências. São Paulo: Governo, 2016.

SCOTT, Joan Wallach. Género: todavía una categoría útil para el análisis. La Manzana de la Discordia, Calli, v. 6, n. 1, p. 95-101, ene./jun. 2011.

SCOTT, Joan Wallach. Gênero: uma categoria útil para a análise histórica. Educação \& Realidade, Porto Alegre, v. 20, n. 2, p. 71-99, jul./dez. 1995.

SERGIPE. Decreto de Lei $n^{0}$ 8.025, de 4 de setembro de 2015. Aprova o Plano Estadual de Educação (PEESE) e dá outras providências. Aracajú: Governo, 2015.

SILVA, Amanda; CÉSAR, Maria Rita de Assis. A emergência da "ideologia de gênero" no discurso católico. InterMeio, Campo Grande, v. 23, n. 46, p. 193-213, jul./dez. 2017.

TOCANTINS. Decreto de Lei n 2.977, de 8 de julho 2015. Aprova o Plano Estadual de Educação (PEE-TO) e dá outras providências. Palmas: Governo, 2015.

VIANNA, Cláudia Pereira; UNBEHAUM, Sandra. Contribuições da produção acadêmica sobre gênero nas políticas educacionais: elementos para repensar a agenda. In: CARREIRA, Denise et al. (Org.). Gênero e educação: fortalecendo uma agenda para as políticas educacionais. São Paulo: Ação Educativa: Cladem: Ecos: Geledés: Fundação Carlos Chagas, 2016. p. 55-120. 
VIANNA, Cláudia Pereira; UNBEHAUM, Sandra. Gênero na educação básica: quem se importa? Uma análise de documentos de políticas públicas no Brasil. Educação \& Sociedade, Campinas, v. 28, n. 95, p. 407-28, maio/ago. 2006.

VIANNA, Cláudia Pereira; UNBEHAUM, Sandra. 0 gênero nas políticas públicas de educação. Cadernos de Pesquisa, São Paulo, v. 34, n. 121, p. 77-104, 2004.

VIANNA, Cláudia Pereira. Políticas de educação, gênero e diversidade sexual: breve história de lutas, danos e resistências. Belo Horizonte: Autêntica, 2018.

VIEIRA, Evaldo. 0s direitos sociais e a política social. São Paulo: Cortez, 2007.

Recebido em: 25.03.2019 Revisado em: 20.08.2019 Aprovado em: 01.10.2019

Cláudia Vianna é professora sênior da Faculdade de Educação da Universidade de São Paulo (USP) com mestrado na Pontifícia Universidade Católica de São Paulo (PUC-SP), doutorado e livre-docência em Educação, ambos pela USP. Pós-doutorado em Gênero e Educação pela Universidad Autónoma de Madrid (UAM). Líder do Grupo de Estudos de Gênero, Educação e Cultura Sexual (Edges/FEUSP) e bolsista PQ nível 1 D pelo CNPq.

Alexandre Bortolini é pedagogo e comunicador social. Mestre em Educação pela Pontifícia Universidade Católica do Rio de Janeiro (PUC-Rio); doutorando em Educação pela Universidade de São Paulo (USP); Visiting Research Scholar da City University of New York (2019). Consultor OEl e PNUD; coordenador do Projeto Diversidade Sexual na Escola 2006-2016 na Universidade Federal do Rio de Janeiro (UFRJ) e membro da equipe da Coordenação-Geral de Direitos Humanos (MEC, 2013 e 2015). Integrante do Edges (FEUSP). 